\title{
Response of Zonal and Ivy Geraniums to Root Medium pH
}

\author{
Pauline H. Andrews ${ }^{1}$ and P. Allen Hammer ${ }^{2}$ \\ Department of Horticulture and Landscape Architecture, 625 Agriculture \\ Mall Drive, Purdue University, West Lafayette, IN 47907-2010
}

Additional index words. lime, greenhouse production, soilless media

\begin{abstract}
Three cultivars each of zonal geranium (Pelargonium $\times$ hortorum 'Candy Lavender', 'Fireball', and 'Patriot Red') and ivy geraniums (Pelargonium pelatum 'Global Deep Lilac', 'Global Salmon Rose', and 'Global Soft Pink') were grown in root media with pHs varying from 4.3 to 7.8. In Expt. 1, a mixture of sphagnum peat, fine perlite, and fine pine bark was modified with limestone and hydrated lime at the following rates: $0,1.2$, $3.0,4.7$, and $11.9 \mathrm{~kg} \cdot \mathrm{m}^{-3}$ limestone; 11.9 limestone plus 5.9 hydrated lime; 11.9 limestone plus 8.3 hydrated lime; and $11.9 \mathrm{~kg} \cdot \mathrm{m}^{-3}$ limestone plus $10.7 \mathrm{~kg} \cdot \mathrm{m}^{-3}$ hydrated lime to give the various root medium $\mathrm{pH}$ treatments. Plants were grown for 11 weeks in glass greenhouses. In Expt. 2, plants were grown in two commercial soilless mixes with one being modified with the addition of $0 \mathrm{~kg} \cdot \mathrm{m}^{-3}$ limestone, $6.0 \mathrm{~kg} \cdot \mathrm{m}^{-3}$ limestone plus 0.6 $\mathrm{kg} \cdot \mathrm{m}^{-3}$ hydrated lime, and $6.0 \mathrm{~kg} \cdot \mathrm{m}^{-3}$ limestone plus $2.4 \mathrm{~kg} \cdot \mathrm{m}^{-3}$ hydrated lime. In both experiments, greatest dry weight was recorded in zonal and ivy geraniums plants grown at root medium pHs above 6.4. This study showed a root medium $\mathrm{pH}$ of 6.4 to 6.5 should be recommended for the greenhouse production of both zonal and ivy geraniums.
\end{abstract}

Potted geraniums are a significant part of the U.S. bedding plant industry. The USDA reported that in 2002, potted geraniums accounted for $\$ 150$ million in wholesale value, more than any other bedding or garden plant surveyed. In addition, almost $15 \%$ of flowering hanging basket production in 2003 was geraniums (USDA, 2003).

Despite the importance of the geranium in floriculture production, little published research is available on the root medium $\mathrm{pH}$ requirements for zonal and ivy geraniums for maximum growth. Current recommendations for zonal geraniums are a root medium $\mathrm{pH}$ of 5.7 to 6.6 (Argo and Fisher, 2002; Bethke, 1993; Biamonte et al., 1993; Hammer, 1988; Sheely and Craig, 1993). The upper range of the recommendations is to avoid potential micronutrient deficiencies, especially iron.

The lower range for the $\mathrm{pH}$ recommendation is to avoid iron and manganese toxicity in geraniums at low $\mathrm{pH}$. Geranium roots excrete hydrogen ions, carboxyl groups, and acidic organic substances to aid in nutrient uptake (Paul and Clark, 1989), which can lead to a lowering of $2 \mathrm{pH}$ units in root medium in direct contact with roots (Marschner, 1986). If root medium $\mathrm{pH}$ is not controlled, iron and manganese toxicity increases as root media $\mathrm{pH}$ decreases.

\footnotetext{
Received for publication 14 Mar. 2006. Accepted for publication 28 May 2006. This research was partially supported by a grant from the Ken Post/Herman Schenkel Foundation. Publication number 2006-17906 of the Purdue University Office of Agricultural Research. We thank The Scotts Company for supplying root media and Oglevee Ltd. for supplying rooted cuttings for this study.

${ }^{1}$ Graduate research assistant.

${ }^{2}$ Professor; to whom reprint requests should be addressed; e-mail hammer@purdue.edu.
}

Even less data on optimum root medium $\mathrm{pH}$ are available for ivy geraniums. (Holcomb and O'Donovan 1993) state the root medium $\mathrm{pH}$ for ivy geraniums must be maintained within close tolerances to avoid nutritional disorders. However, the literature gives a wide range of $\mathrm{pH}$ recommendations for ivy geraniums, from $\mathrm{pH} 5.0$ to 6.2 (Argo and Fisher, 2002; Sheely and Craig, 1993; Trellinger, 1997; Whipker 1998). It is also recommended that ivy geraniums be grown at 0.3 to $0.5 \mathrm{pH}$ units lower than zonal geraniums (Holcomb and O'Donovan, 1993; Whipker, 1998).

The wide range in root medium $\mathrm{pH}$ recommendations for both zonal and ivy geraniums and the lack of research data on optimum $\mathrm{pH}$ for maximum plant growth prompted this research. Also, the basis for the recommendation of a lower root medium $\mathrm{pH}$ for ivy geraniums than zonal geraniums cannot be found in published literature. A more precise root medium $\mathrm{pH}$ recommendation for both zonal and ivy geraniums will remove the present uncertainty. The objectives of this research are to investigate the effect of root medium $\mathrm{pH}$ on the growth and development of zonal and ivy geraniums and to determine more precise root medium $\mathrm{pH}$ recommendations for zonal and ivy geranium production.

\section{Materials and Methods}

Two separates studies were conducted to evaluate the effect of root medium $\mathrm{pH}$ on the growth of zonal and ivy geraniums.

\section{Expt. 1}

Two liming materials were incorporated, a pulverized dolomitic carbonate limestone (99.07\% $\mathrm{CaCO}_{3} \cdot \mathrm{MgCO}_{3}$, OSHO Pulverized Limestone; Great Lakes Calcium Corp.,
Woodville, Ohio) and hydrated lime (HiYield Horticultural Hydrated Lime. Voluntary Purchasing Groups, Inc., Bonham, Texas). A screening of the pulverized limestone showed $100 \%$ of the material passed through a 450- $\mu \mathrm{m}$ (\# 40) screen, $80 \%$ passed through a $180-\mu \mathrm{m}$ (\# 80) screen, $45 \%$ passed through a 90- $\mu \mathrm{m}$ (\# 170) screen, and $20 \%$ passed through a $45-\mu \mathrm{m}$ (\# 325) screen.

A root medium of 1:1:1 mix of fine sphagnum peat, fine perlite, and fine pine bark was used in the study (individual components from The Scotts Company, Marysville, Ohio). Eight lime treatments were used with limestone and hydrated lime at the following rates: $0,1.2,3.0,4.7$, and 11.9 $\mathrm{kg} \cdot \mathrm{m}^{-3}$ limestone; 11.9 limestone plus 5.9 hydrated lime; 11.9 limestone plus 8.3 hydrated lime; or $11.9 \mathrm{~kg} \cdot \mathrm{m}^{-3}$ limestone plus $10.7 \mathrm{~kg} \cdot \mathrm{m}^{-3}$ hydrated lime. Sufficient reverse-osmosis ( $\mathrm{RO}$ ) water was added at mixing to bring the moisture content of the medium to $40 \%$ to $50 \%$ of container capacity and the root medium was allowed to equilibrate for $3 \mathrm{~d}$ before transplanting. A preplant nutrient charge consisting of $0.6 \mathrm{~kg} \cdot \mathrm{m}^{-3} 12$ 12-12 fertilizer (Parker's; Pursell Industries, Inc., Sylacauge, Ala.) and $0.04 \mathrm{~kg} \cdot \mathrm{m}^{-3}$ micronutrient fertilizer (Peters S.T.E.M.; The Scotts Company, Marysville, Ohio) was incorporated into the media.

Three cultivars each of zonal geranium (Pelargonium x hortorum 'Candy Lavender', 'Fireball', and 'Patriot Red') and ivy geraniums (Pelargonium pelatum 'Global Deep Lilac', 'Global Salmon Rose', and 'Global Soft Pink') were potted on 30 May 2003. Rooted cuttings were potted into $7.6 \mathrm{~cm}^{3}$ pots (T.O. Plastics Inc., Minneapolis, Minn.) containing root medium from each of the eight lime treatments (30 single-pot replicates) for a total of 1440 pots. Pots were arranged in a completely randomized design over three benches in a glasshouse section with cement floors. Air temperatures were maintained at set points of $23.9{ }^{\circ} \mathrm{C} \mathrm{D} / 19.4{ }^{\circ} \mathrm{C} \mathrm{N}$. Plants were irrigated to container capacity as needed with RO water containing a $15-5-15$ commercial fertilizer formulation (Miracle Gro Excel Cal-Mag; The Scotts Co., Marysville, Ohio), which provided (in $\mathrm{mg} \cdot \mathrm{L}^{-1}$ ) $250 \mathrm{~N}, 36$ P, $209 \mathrm{~K}, 84 \mathrm{Ca}, 38 \mathrm{Mg}$, and trace elements.

Ten plants per cultivar per lime treatment were randomly selected and harvested at weeks 3, 6, and 11 after transplanting. Shoot dry weight and root media $\mathrm{pH}$ were determined at each harvest. Root medium was sampled from the root zone, and the root media $\mathrm{pH}$ of the sample was determined by the saturated paste method using RO water. An additional media nutrient analysis was performed on medium from the root zone of three randomly selected pots per treatment of the zonal geranium cultivars 'Candy Lavender' and 'Fireball'. Nutrients contained in each sample were tested using the SME method with RO water as the extractant (Warncke, 1986). EC and macronutrients were measured in the extracted solution. Medium EC and nitrate $\mathrm{N}$ were determined with a platinum electrode at a standard $25^{\circ} \mathrm{C}$ 
and $\mathrm{NH}_{4}{ }^{+}-\mathrm{N}$ by the Nessler method (Jackson, 1958) and $\mathrm{PO}_{4}^{-2}-\mathrm{P}$ with a modified MurphyRiley procedure (Murphy and Riley, 1962). Medium $\mathrm{K}^{+}, \mathrm{Mg}^{+2}$, and $\mathrm{Ca}^{+2}$ were determined using flame emission using a Varian SpectrAA-10 spectrometer (Varian Tectron, Mulgrave, Victoria, Australia).

Leaf color luminance, chroma, and hue angle were determined at week 10 after transplanting using a Minolta CR-200 chromometer (Minolta, Ramsey, N.J.) with diffuse illumination, $0^{\circ}$ viewing angle, CIE illuminant $\mathrm{C}$, and an 8-mm specimen aperture size. The chromometer was calibrated using calibration plate CR-AR-A60 (Minolta). Measurements were taken on two mature leaves (eighth or ninth node) per plant. The color measurement was taken on green leaf tissue just inside the red leaf band on zonal geranium leaves and on green leaf tissue just outside the red leaf spot in the center of the ivy geranium leaves. Because color was measured in the CIELAB scale $\left(\mathrm{L}^{*}, \mathrm{a}^{*}, \mathrm{~b}^{*}\right)$, the variable $\mathrm{L}^{*}$ is a direct measure of the color's luminance. Chroma and hue angle were calculated from the variables $a^{*}$ and $b^{*}$. Chroma was calculated as $\left(a^{* 2}+b^{* 2}\right)^{1 / 2}$ and hue was calculated from the arctangent of b*/a* (McGuire, 1992).

\section{Expt. 2}

Geraniums were grown in two commercial soilless root media: Metro-Mix 366-P with Coir (Sun Gro Horticulture, Bellevue, Wash.) and PRO-MIX 'BX' (Premier Horticulture Ltd., Dorval, Quebec, Canada). The MetroMix media is composed of peat, perlite, and bark and was structurally similar to the medium used in Expt. 1. Limestone and hydrated lime (from Expt. 1) were incorporated into the Metro-Mix media at the following rates: $0 \mathrm{~kg} \cdot \mathrm{m}^{-3}$ limestone, $6.0 \mathrm{~kg} \cdot \mathrm{m}^{-3}$ limestone plus $0.6 \mathrm{~kg} \cdot \mathrm{m}^{-3}$ hydrated lime, and $6.0 \mathrm{~kg} \cdot \mathrm{m}^{-3}$ limestone plus $2.4 \mathrm{~kg} \cdot \mathrm{m}^{-3}$ hydrated lime. The PRO-MIX 'BX' media was used with no additional limestone or hydrated lime incorporated, creating a total of four media-lime treatments. Sufficient RO water was added at mixing to bring the moisture content of the medium to $40 \%$ to $50 \%$ of container capacity and the medium was allowed to equilibrate for $3 \mathrm{~d}$ before transplanting.

The same three cultivars of both zonal and ivy geraniums as used in Expt. 1 were potted on 31 Dec. 2003. Rooted cuttings were potted into $7.6 \mathrm{~cm}^{3}$ pots (T.O. Plastics Inc., Minneapolis, Minn.) containing one of the four media lime treatments ( 20 single-pot replicates) for a total of 480 pots. Pots were completely randomized over two benches in a glasshouse section with cement floors. Air temperatures were maintained at set points of $23.9^{\circ} \mathrm{C} \mathrm{D} / 19.4^{\circ} \mathrm{C}$ N. From transplanting up to $6 \mathrm{wk}$ after transplanting, plants were irrigated to container capacity as needed with greenhouse water containing a $15-5-15$ commercial fertilizer formulation (Miracle Gro Excel Cal-Mag; The Scotts Co.), which provided (in $\mathrm{mg} \cdot \mathrm{L}^{-1}$ ) $250 \mathrm{~N}, 36 \mathrm{P}, 209 \mathrm{~K}, 84 \mathrm{Ca}$, $38 \mathrm{Mg}$, and trace elements. Adjustment of $\mathrm{pH}$ to range 5.7 to 6.0 and alkalinity reduction was achieved with 93\% sulfuric acid (Ulrich Chemical, Indianapolis, Ind.) at $0.08 \mathrm{ml} \cdot \mathrm{liter}^{-1}$. At week 6 after transplanting, plants were then irrigated with fertilizer water using nonacidified water with an initial $\mathrm{pH}$ of 7.2 and $280 \mathrm{ppm} \mathrm{HCO}_{3}^{-}$.

Ten plants per cultivar per lime treatment were randomly selected and harvested each at weeks 6 and 11 after transplanting. Shoot dry weight and root medium $\mathrm{pH}$ were determined at each harvest. Root medium was sampled from the root zone area and the root medium $\mathrm{pH}$ of the sample was determined by the saturated paste method using $\mathrm{RO}$ water.

SAS software (SAS Institute, Cary, N.C.) was used for all statistical analyses. Type III sums of squares were used to test hypotheses and Tukey's multiple comparison test $(P<$ $0.05)$ was used to compare treatment means.

\section{Results and Discussion}

\section{Expt. 1}

Root medium $p H$. Lime treatment, week, and the lime treatment $\times$ week interaction were each significant at $P<0.001$. Average root medium $\mathrm{pH}$ increased significantly as lime addition increased with the exception of the two highest lime treatments (root medium $\mathrm{pH}$ of 7.25 and 7.30, respectively), which were not significantly different (Fig. 1). Root medium $\mathrm{pH}$ also decreased significantly from week 3 to week 11, dropping an average of $0.84 \mathrm{pH}$ units over time. Because the plants were irrigated with $\mathrm{RO}$ water, containing no measurable alkalinity, the drop in root media $\mathrm{pH}$ over time could be a result of the ability of geraniums to lower root medium $\mathrm{pH}$ through the excretion of compounds such as acidic organic substances to aid in nutrient uptake (Paul and Clark, 1989).

The greatest decrease in root medium $\mathrm{pH}$ from week 3 to week 11 occurred in the two lime treatments with the highest hydrated lime additions, in which 8.3 or $10.7 \mathrm{~kg} \cdot \mathrm{m}^{-3}$ hydrated lime plus $11.9 \mathrm{~kg} \cdot \mathrm{m}^{-3}$ limestone were incorporated. A decrease in root media
$\mathrm{pH}$ of 1.28 and $1.19 \mathrm{pH}$ units, respectively, occurred in the two lime treatments. The large decrease in root media $\mathrm{pH}$ may be a result of the high hydrated lime additions to these treatments, which reacts very quickly and may also be more easily leached out over time.

With the exception of the $0 \mathrm{~kg} \cdot \mathrm{m}^{-3}$ limestone treatment, the smallest decrease in root medium $\mathrm{pH}$ between week 3 and week 11 occurred in the treatment with $11.9 \mathrm{~kg} \cdot \mathrm{m}^{-3}$ limestone, which was the highest limestone rate with no hydrated lime added. A decrease of only $0.53 \mathrm{pH}$ units was observed. It is known that limestone applications increase root medium $\mathrm{pH}$; the effect diminishes at high limestone rates (Wiedenfeld and Cox, 1988). However, the high limestone rate may have helped prevent a greater decrease in root media $\mathrm{pH}$ over time.

Plant dry weight. Cultivar, lime treatment, week, and the lime treatment $\times$ week interaction were significant $(P<0.001)$ for zonal geraniums. Plant dry weight at weeks 3 , 6 , and 11 is presented in Fig. 2. At week 3, little variation of plant dry weight in zonal geraniums was observed across the root media $\mathrm{pH}$ values. Although plant dry weight had increased overall by week 6 , the lowest plant dry weight at that time was observed at the highest root media $\mathrm{pH}$. At a root media $\mathrm{pH}$ of 7.36 and 4.41 , plant dry weight was only 4.34 and $4.02 \mathrm{~g}$, respectively. The two highest $\mathrm{pH}$ values correspond to the two lime treatments with the highest hydrated lime additions. Three weeks earlier, the same lime treatments had a root medium $\mathrm{pH}$ of 7.83 and 7.84 , respectively. The high root medium $\mathrm{pH}$ at that time may have adversely affected plant growth over the next 3 weeks, resulting in less plant growth rate as compared with the other lime treatments. At week 11, plant dry weight of zonal geraniums increased as root medium $\mathrm{pH}$ increased. A plant dry weight of only $8.42 \mathrm{~g}$ occurred at a root medium $\mathrm{pH}$ of 4.31. The greatest plant dry weight of $12.72 \mathrm{~g}$ occurred a root medium $\mathrm{pH}$ of 6.65 in zonal

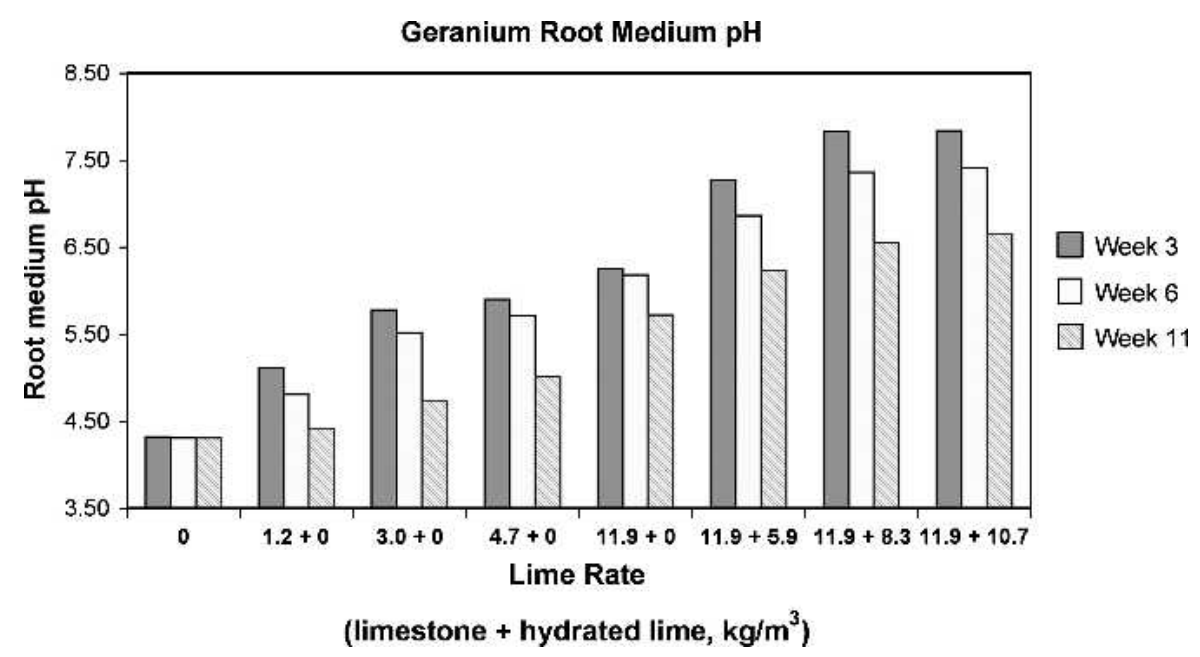

Fig. 1. Effect of lime incorporation rate on root media $\mathrm{pH}$ of zonal and ivy geraniums at weeks 3,6 , or 11 after transplanting. Limestone and hydrated lime was incorporated at increasing rates into a media composed of 1:1:1 sphagnum peat, perlite, and composted pine bark. The interaction lime treatment $\times$ week was significant at $P<0.001$. 
geraniums and corresponds to the lime treatment with the greatest limestone lime addition, $11.9 \mathrm{~kg} \cdot \mathrm{m}^{-3}$ limestone plus $10.7 \mathrm{~kg} \cdot \mathrm{m}^{-3}$ hydrated lime.

Cultivar, lime treatment, lime treatment $x$ week interaction, and cultivar $\times$ week interaction were each significant at $P<0.001$ for ivy geraniums. At week 3, plant dry weight in ivy geraniums is similar between root medium $\mathrm{pH}$ values of 4.32 and 7.27 (Fig. 2). Plant dry weight showed little variation at week 3 with plant dry weights of only 1.46 and $1.59 \mathrm{~g}$ at root medium $\mathrm{pH}$ of 7.83 and 7.84 , respectively. Plant dry weight of ivy geraniums had increased in all treatments by week 6 . As root medium $\mathrm{pH}$ increased from $\mathrm{pH} 4.31$ to 6.25 , plant dry weight increased from 4.32 to $5.30 \mathrm{~g}$. However, as root medium $\mathrm{pH}$ increased from 6.25 to 7.41 , plant dry weight decreased from 5.30 to $4.07 \mathrm{~g}$. Like in the case of the zonal geraniums, the high root medium $\mathrm{pH}$ of the two highest lime treatments at week 3 may have adversely affected plant growth by week 6 , resulting in less plant growth rate as compared with the other lime treatments. By week 11, plant dry weight increased as root medium $\mathrm{pH}$ increased. The smallest plant dry weight of $8.82 \mathrm{~g}$ occurred at a root media $\mathrm{pH}$ of 4.31 . The greatest plant dry weight in ivy geraniums, $11.04 \mathrm{~g}$, occurred a root medium $\mathrm{pH}$ of 6.65 , which corresponds to the lime treatment with the greatest lime addition, $11.9 \mathrm{~kg} \cdot \mathrm{m}^{-3}$ limestone plus $10.7 \mathrm{~kg} \cdot \mathrm{m}^{-3}$ hydrated lime.

Leaf color. Cultivar, lime treatment, and the interaction cultivar $\times$ lime treatment were significant $(P<0.001)$ for luminance, chroma, and hue angle. Because two leaves were sampled per plant, a split-plot test was performed to determine if sampling had an affect on leaf color measurements. Sampling was not significant at $P<0.001$ for luminance, chroma, or hue. Leaf luminance values for each cultivar are presented in Fig. 3 and are plotted against the mean lime treatment root medium $\mathrm{pH}$ recorded at week 11 . Leaf luminance decreased as lime addition increased, corresponding to leaves that are darker in color as root medium $\mathrm{pH}$ increased. The two highest lime treatments had significantly lower luminance levels $(P<0.05)$ than the other treatments, with mean luminance levels of 42.6 and 38.6, respectively. Similar results were seen in leaf chroma and hue (data not shown). Leaf chroma values decreased as lime addition increased, corresponding to leaves that are less vivid in color with increased root medium $\mathrm{pH}$. The highest lime treatment had a significantly lower chroma level $(P<0.05)$ than that of the other lime treatments. Leaf hue values increased as lime addition increased, corresponding to leaves that are more green (less yellowgreen) in color as root medium $\mathrm{pH}$ increased. The highest lime treatment had a significantly greater hue value $(P<0.05)$ than the other lime treatments. Overall, leaves were darker, less vivid, and deeper green in color as root medium $\mathrm{pH}$ increased.

Media analysis. Nutrient analyses at week 11 are presented in Fig. 4. The levels of
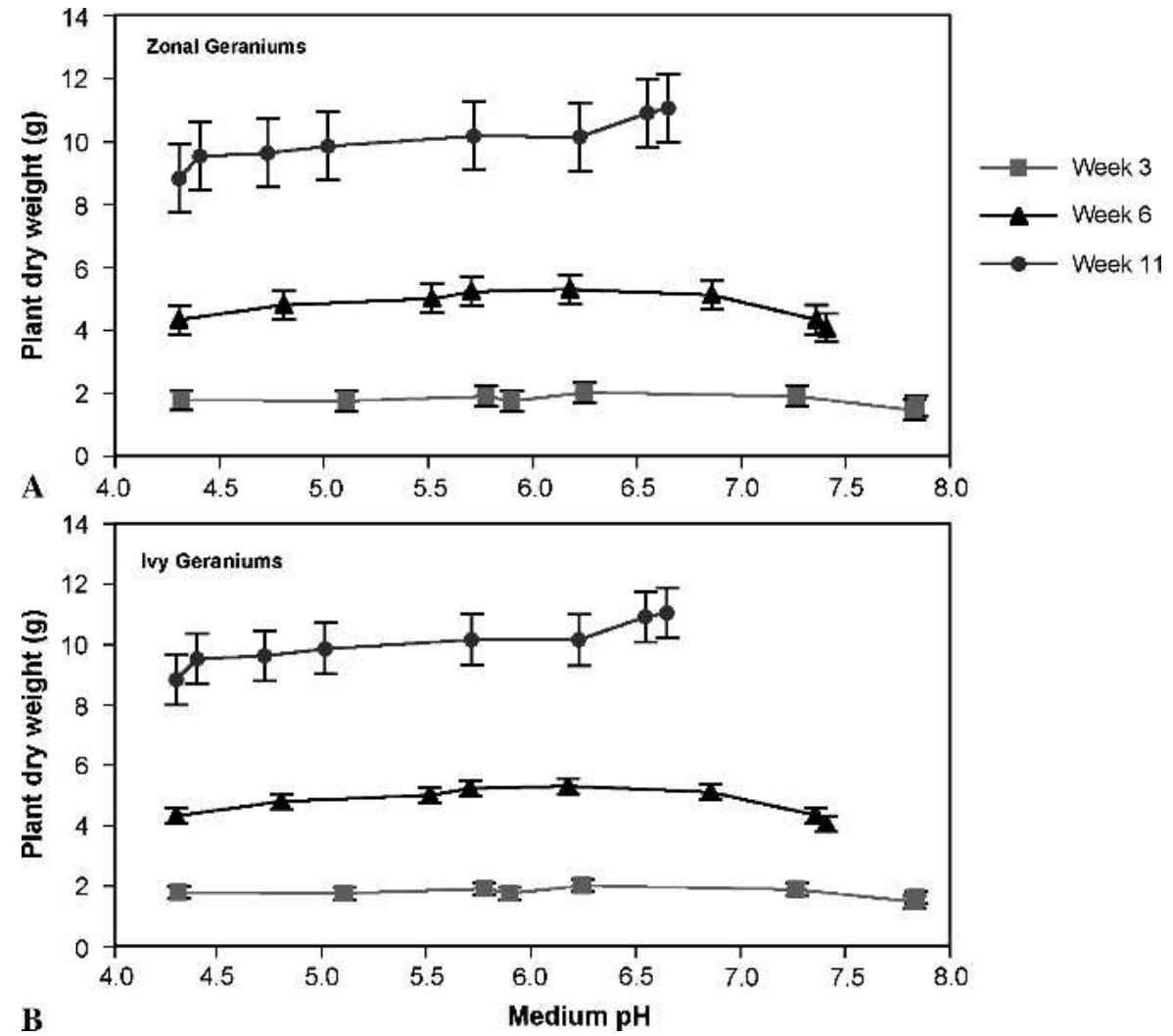

Fig. 2. Effect of root media $\mathrm{pH}$ on average plant dry weight of zonal or ivy geraniums at weeks 3,6 , or 11 after transplanting. Error bars indicating the least significant difference of the lime treatment $\times$ week interaction are shown. Zonal geranium plant dry weight of each cultivar was significantly different at $P<0.05$ with a mean of $6.14,5.78$, and $5.46 \mathrm{~g}$ for cultivars 'Candy Lavender', 'Patriot Red' and 'Fireball'. Ivy geranium plant dry weight of each cultivar was significantly different at $P<0.05$ with a mean of 6.04, 5.55, and $4.94 \mathrm{~g}$ for cultivars 'Global Salmon Rose', 'Global Soft Pink' and 'Global Deep Lilac'.

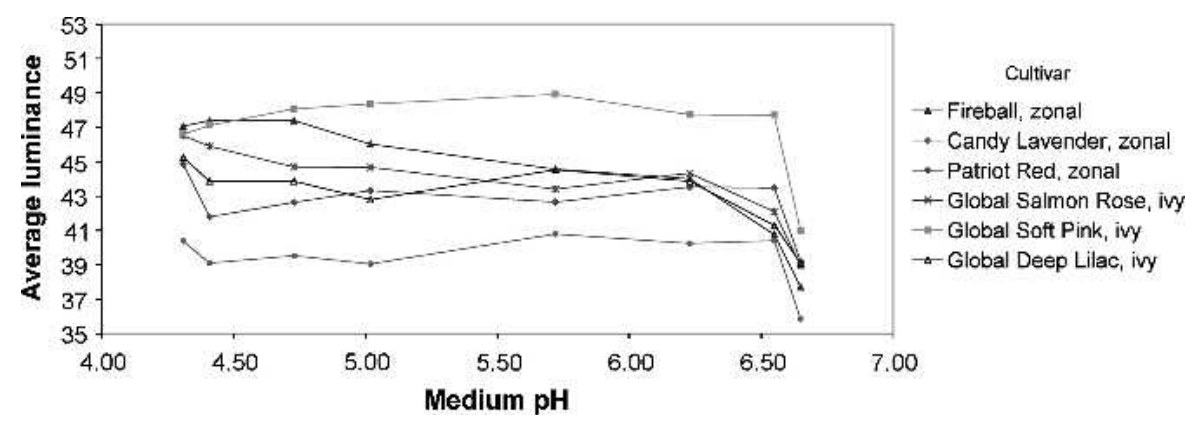

Fig. 3. Effect of root medium $\mathrm{pH}$ on leaf luminance of six cultivars of zonal and ivy geraniums at week 11 . Color was measured in the CIELAB scale using a Minolta CR-200 chromometer.

ammonium, calcium, magnesium, nitrate, phosphorous, and total soluble salts for each geranium species are plotted against the mean lime treatment root media $\mathrm{pH}$ recorded at week 11 of the study. As root media $\mathrm{pH}$ increased, calcium and magnesium levels increased. At the same time, phosphorous levels decreased with the increase in root media $\mathrm{pH}$. Calcium and magnesium levels would increase as a result of the higher rates of lime added and an increase in availability as root media $\mathrm{pH}$ increases. The decrease in phosphorus levels may be a result of the increasing calcium levels because calcium forms an insoluble complex with phosphorus as root media $\mathrm{pH}$ increases. As root media $\mathrm{pH}$ increased, ammonium levels decreased and nitrate levels increased. This effect is attributed to root media $\mathrm{pH}$; at low root media $\mathrm{pH}$, the predominant form of nitrogen is ammonium in which the predominant becomes nitrate as root media $\mathrm{pH}$ increases. Soluble salt levels also increased with an increase in root media $\mathrm{pH}$. The higher EC levels would be the result of increase nutrient availability as root media $\mathrm{pH}$ increases.

\section{Expt. 2}

Medium $\mathrm{pH}$. Root medium $\mathrm{pH}$ was significantly different for cultivar, media treatment, week, and the interaction media treatment $\times$ week $(P<0.001)$. Although the 

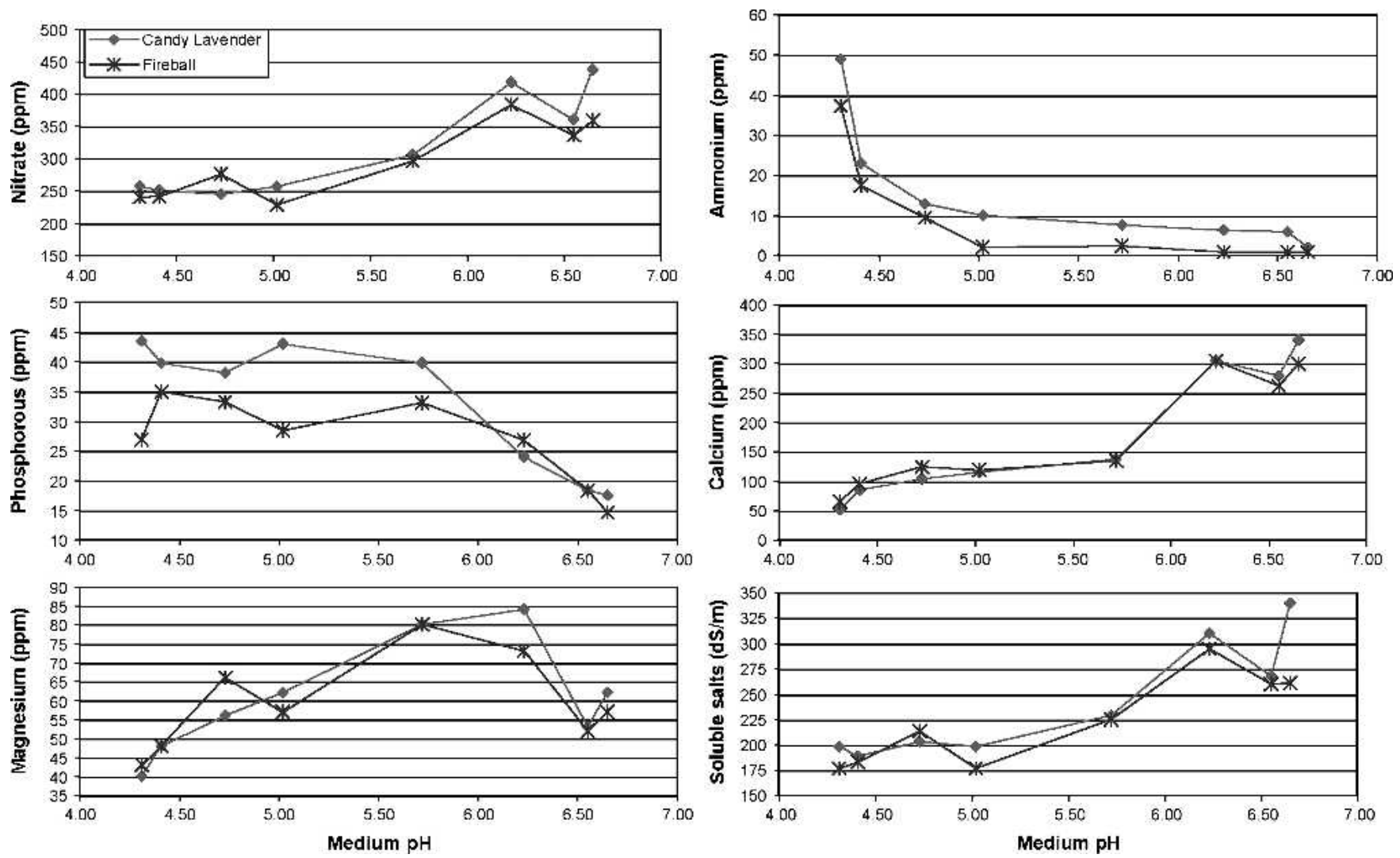

Fig. 4. Effect of root media pH on calcium, magnesium, ammonium, phosphorous, soluble salts, or nitrate levels of two zonal geranium cultivars, 'Candy Lavender' and 'Fireball'. Media nutrient analysis of the root media was determined at week 11 of the study using the SME method with RO water as the extractant. The nutrients ammonium, calcium, magnesium, nitrate, phosphorous, and total soluble salts were measured in the extracted solution. Cultivar was significant at $P<0.0001$ for ammonium and $P<0.005$ for phosphorous. The interaction cultivar $\times$ lime treatment was significant at $P<0.05$ for phosphorous.

only significant difference among cultivars was a $0.27 \mathrm{pH}$ unit difference between zonal geranium cultivars, 'Candy Lavender' and 'Fireball', and cultivar 'Patriot Red', the average root medium $\mathrm{pH}$ in Metro-Mix increased significantly as lime addition increased (Fig. 5). The PRO-MIX 'BX' treatment had the lowest root media $\mathrm{pH}$, at $\mathrm{pH}$ 5.80, and was significantly lower in root media $\mathrm{pH}$ than the unlimed Metro-Mix treatment. Root medium $\mathrm{pH}$ also increased significantly from week 6 to week 11 , increasing an average of $0.25 \mathrm{pH}$ units over time, and is attributed to the use of nonacidified tap water with high alkalinity (280 ppm $\mathrm{HCO}_{3}^{-}$).

Plant dry weight. Cultivar, media treatment, week, and cultivar $\times$ week interaction were each significant at $P<0.001$ for both the zonal and ivy geraniums. In addition, the cultivar $\times$ media treatment interaction was significant at $P<0.05$ for zonal geraniums. Plant dry weight is presented in Fig. 6. For zonal geraniums grown in Metro-Mix, the highest plant dry weights were measured for each cultivar when $6.0 \mathrm{~kg} \cdot \mathrm{m}^{-3}$ limestone plus 0.6 $\mathrm{kg} \cdot \mathrm{m}^{-3}$ hydrated lime was incorporated into the root medium. This media treatment had a mean root media $\mathrm{pH}$ of 6.40 at week 11 (Fig. 5).

Although the $\mathrm{pH}$ of the PRO-MIX 'BX' medium was 6.15 and was similar to that of the unlimed Metro-Mix treatment, plant dry weight was greater for plants grown in PROMIX 'BX' than those grown in unlimed
Metro-Mix for all cultivars with the exception of 'Fireball'. Plant dry weight was $0.07 \mathrm{~g}$ greater in the PRO-MIX 'BX' treatment than Metro-Mix treatment with $6.0 \mathrm{~kg} \cdot \mathrm{m}^{-3}$ limestone plus $0.6 \mathrm{~kg} \cdot \mathrm{m}^{-3}$ hydrated lime in 'Candy
Lavender'. In 'Fireball' and 'Patriot Red', plant dry weight in the PRO-MIX 'BX' treatment is less than that in Metro-Mix treatment with $6.0 \mathrm{~kg} \cdot \mathrm{m}^{-3}$ limestone plus $0.6 \mathrm{~kg} \cdot \mathrm{m}^{-3}$ hydrated lime incorporated. This

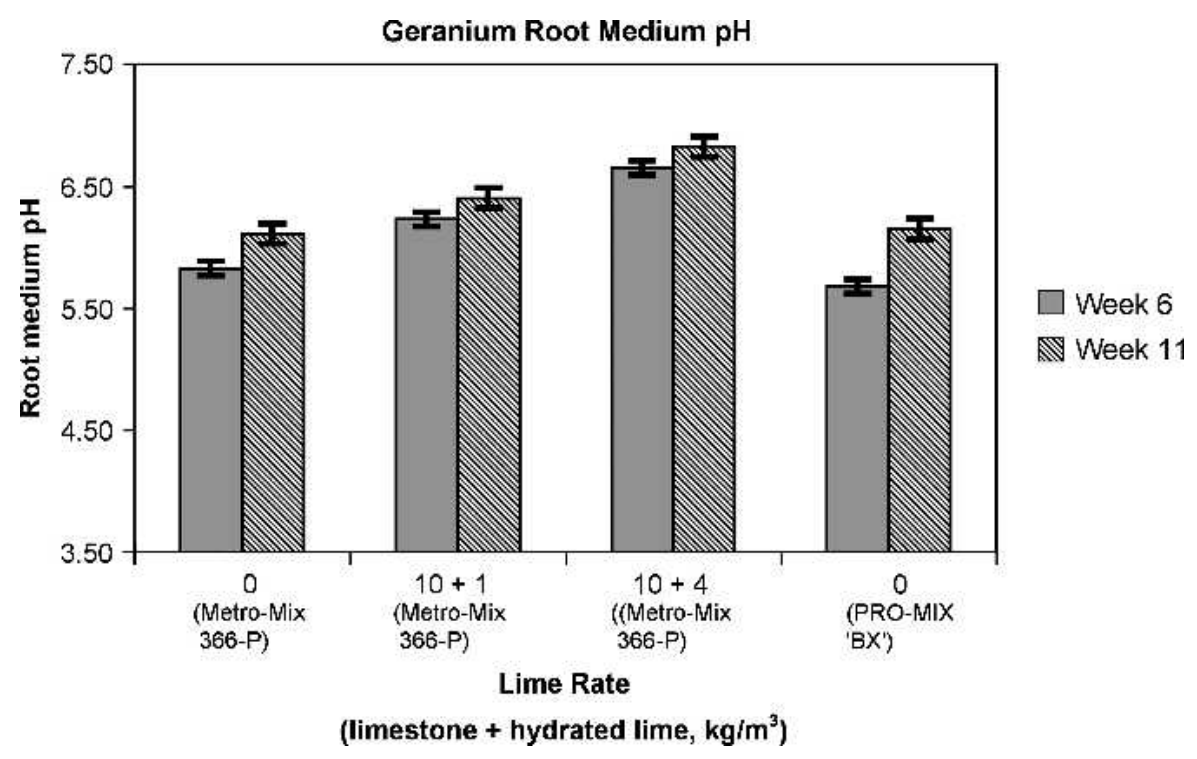

Fig. 5. Effect of lime incorporation rate and media type on root media $\mathrm{pH}$ of zonal and ivy geraniums at weeks 6 or 11 after transplanting. Error bars indicating the least significant difference of the lime treatment $\times$ week interaction are shown. Geraniums were grown in Sun Gro's Metro-Mix 366-P or PRO-MIX 'BX'. Limestone and hydrated lime was incorporated into the Metro-Mix 366-P at increasing rates. The interaction media $\times$ week was significantly at $P<0.001$. 

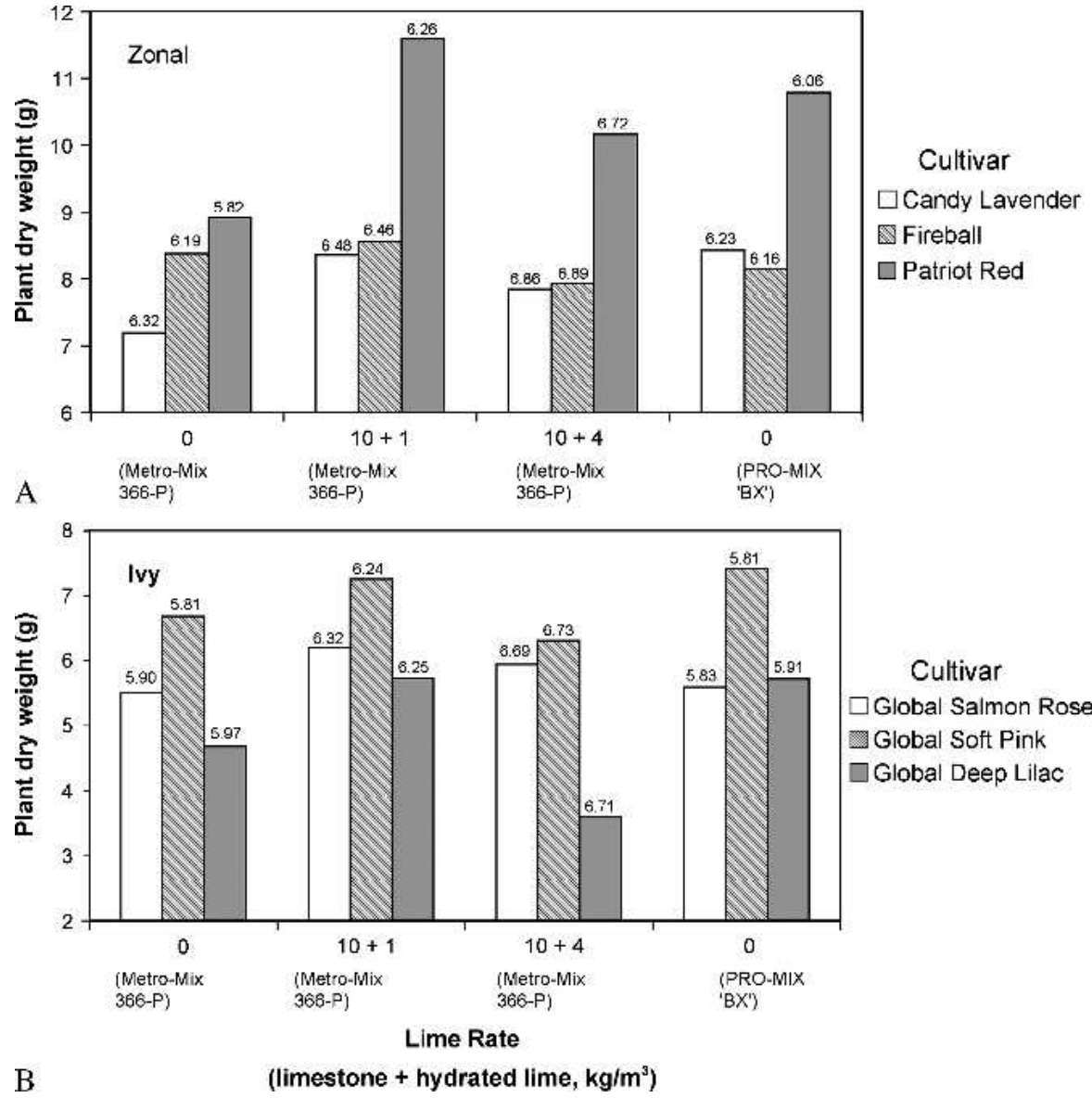

Fig. 6. Effect of lime incorporation rate and media type on plant dry weight of three zonal geranium cultivars and three ivy geranium cultivars at week 11. Sun Gro Metro-Mix 366-P and PRO-MIX 'BX' were used in the study and limestone and hydrated lime was incorporated at increasing rates into the Sun Gro Metro-Mix 366-P mix. Medium pH at week 11 is shown at the top of each bar.

may suggest that an increase in root media $\mathrm{pH}$ of PRO-MIX 'BX' could lead to increased plant growth of these cultivars.

Cultivar, media treatment, week, and cultivar $\times$ week interaction were each significant at $P<0.001$ and the cultivar $\times$ media treatment interaction was significant at $P<$ 0.01 for ivy geraniums. In ivy geraniums, the greatest plant dry weight in the Metro-Mix treatments occurred in the root medium treatment Metro-Mix incorporated with 6.0 $\mathrm{kg} \cdot \mathrm{m}^{-3}$ limestone plus $0.6 \mathrm{~kg} \cdot \mathrm{m}^{-3}$ hydrated lime for cultivars 'Global Salmon Rose', 'Global Soft Pink', and 'Global Deep Lilac'. Like with the zonal geraniums, plant dry weight was greater for ivy geraniums grown in PRO-MIX 'BX' than those grown in unlimed Metro-Mix. In 'Global Soft Pink', the PRO-MIX 'BX' treatment had $0.16 \mathrm{~g}$ greater plant dry weight than Metro-Mix treatment with $6.0 \mathrm{~kg} \cdot \mathrm{m}^{-3}$ limestone plus recommendations suggest zonal geraniums be grown at a root medium $\mathrm{pH}$ between 5.7 and 6.6 and ivy geraniums be grown at a root medium $\mathrm{pH}$ between 5.0 and 6.2. Often it is suggested ivy geraniums be grown at 0.3 to $0.5 \mathrm{pH}$ units lower than zonal geraniums. This study has shown a root medium $\mathrm{pH}$ of 6.4 to 6.5 resulted in the greatest plant dry weight for both zonal and ivy geraniums. This research will benefit greenhouse growers by providing more precise root medium $\mathrm{pH}$ recommendations for both zonal and ivy geraniums. It will also allow growers to grow both ivy and zonal geraniums at the same root medium $\mathrm{pH}$ without a reduction in plant quality.

\section{Literature Cited}

Argo, W.R. and P.R. Fisher. 2002. Understanding $\mathrm{pH}$ Management for Container-Grown Crops. Meister Pub., Willoughby, Ohio. p. 38

Bethke, C.L. 1993. Growing media. In: J. White (ed.), Geraniums IV.Ball Publishing, West Chicago, Ill. p. 3-24.

Biamonte, R.L., E.J. Holcomb, and J.W. White 1993. Fertilization. In: J. White (ed.), Geraniums IV. Ball Publishing, West Chicago, Ill. p. 39-54.

Hammer, P.A. 1988. Nutrition. In: H.K. Tayama (ed.), Tips on Growing Zonal Geraniums. Ohio State University, Columbus, Ohio. p. 15-18.

Holcomb, E.J. and E.J. O’Donovan. 1993. Ivy Geraniums. In: J. White (ed.), Geraniums IV.Ball Publishing, West Chicago, Ill. p. 191-200.

Jackson, M.L. 1958. Soil Chemical Analysis. Prentice-Hall, Englewood Cliffs, N.J.

Marschner, H. 1986. Mineral Nutrition of Higher Plants, 2nd ed. Academic Press Inc. p. 537-561.

McGuire, R.G. 1992. Reporting of objective color measurements. HortScience 27:1254-1255.

Murphy, J. and J.P. Riley. 1962. A modified single solution method for the determination of phosphate in natural waters. Anal. Chim. Acta. 27:31-36.

$0.6 \mathrm{~kg} \cdot \mathrm{m}^{-3}$ hydrated lime. However, plan dry weight in the PRO-MIX 'BX' treatment was less than that in Metro-Mix treatment with $6.0 \mathrm{~kg} \cdot \mathrm{m}^{-3}$ limestone plus $0.6 \mathrm{~kg} \cdot \mathrm{m}^{-3}$ hydrated lime for 'Global Salmon Rose' and 'Global Deep Lilac'. An increase in root medium $\mathrm{pH}$ of PRO-MIX 'BX' could lead to increased plant growth of these cultivars.

\section{Summary}

The results of these studies show root medium $\mathrm{pH}$ has an effect on the growth of zonal and ivy geraniums. In Expt. 1, as root medium $\mathrm{pH}$ increased to $\mathrm{pH} 6.65$, plant dry weight increased and plant leaf color became darker, deeper green in color in both zonal and ivy geraniums by week 11 . In Expt. 2, a Metro-Mix root medium $\mathrm{pH}$ of 6.40 resulted in the greatest plant dry weight in both zonal and ivy geraniums. Current
Paul, E.A. and F.E. Clark. 1989. Soil Microbiology and Biochemistry. Academic Press Inc.

Sheely, J. and R. Craig. 1993. Growing from vegetative propagules. In: J. White (ed.), Geraniums IV. Ball Publishing, West Chicago, Ill. p. $103-112$.

Trellinger, K. 1997. Top 10 tips for perfect ivy geraniums. Grower Talks 61:73-75.

U.S. Department of Agriculture, National Agricultural Statistics Service. Floriculture Crops. 2003 Summary. Sp Cr 6-1 (04)a.Washington, D.C.

Warncke, D.D. 1986. Analyzing greenhouse growth media by the saturation extraction method. HortScience 21:223-225.

Whipker, B.E. 1998. Fertility Management for Geranium. North Carolina Cooperative Extension Service Horticulture Information Leaflet 504.

Wiedenfeld, R.P. and E.L. Cox. 1988. Effects of limestone and irrigation level on salt levels and $\mathrm{pH}$ in potting media. HortScience 23:844845. 